\title{
L-Band InSAR Penetration Depth Experiment, North Slope Alaska
}

\author{
Reginald R. Muskett \\ Geophysical Institute, University of Alaska, Fairbanks, USA \\ Email: reginald.muskett@gmail.com
}

How to cite this paper: Muskett, R.R. (2017) L-Band InSAR Penetration Depth Experiment, North Slope Alaska. Journal of Geoscience and Environment Protection, 5, 14-30.

https://doi.org/10.4236/gep.2017.53002

Received: January 2, 2017

Accepted: February 12, 2017

Published: February 15, 2017

Copyright $\odot 2017$ by author and Scientific Research Publishing Inc. This work is licensed under the Creative Commons Attribution International License (CC BY 4.0).

http://creativecommons.org/licenses/by/4.0/

\section{(c) (i) Open Access}

\begin{abstract}
Since the first spacecraft-based synthetic aperture radar (SAR) mission NASA's SEASAT in 1978 radars have been flown in Low Earth Orbit (LEO) by other national space agencies including the Canadian Space Agency, European Space Agency, India Space Research Organization and the Japanese Aerospace Exploration Agency. Improvements in electronics, miniaturization and production have allowed for the deployment of SAR systems on aircraft for usage in agriculture, hazards assessment, land-use management and planning, meteorology, oceanography and surveillance. LEO SAR systems still provide a range of needful and timely information on large and small-scale weather conditions like those found across the Arctic where ground-base weather radars currently provide limited coverage. For investigators of solidearth deformation attention must be given to the atmosphere on Interferometric SAR (InSAR) by aircraft and spacecraft multi-pass operations. Because radar has the capability to penetrate earth materials at frequencies from the Pto $\mathrm{X}$-band attention must be given to the frequency dependent penetration depth and volume scattering. This is the focus of our new research project: to test the penetration depth of L-band SAR/InSAR by aircraft and spacecraft systems at a test site in Arctic Alaska using multi-frequency analysis and progressive burial of radar mesh-reflectors at measured depths below tundra while monitoring environmental conditions. Knowledge of the L-band penetration depth on lowland Arctic tundra is necessary to constrain analysis of carbon mass balance and hazardous conditions arising from permafrost degradation and thaw, surface heave and subsidence and thermokarst formation at local and regional scales.
\end{abstract}

\section{Keywords}

Alaska, Tundra, SAR/InSAR, Aircraft, Spacecraft 


\section{Introduction}

During the NASA Space Transportation System era the Jet Propulsion Laboratory, California Institute of Technology, flew payload experimental imaging radar systems at the $\mathrm{L}, \mathrm{C}$ and $\mathrm{X}$ frequencies. These technological test missions were known as the Shuttle Imaging Radar (SIR)-A, -B and -C [1] [2] [3]. SIR-A and B used an L-frequency synthetic aperture radar (SAR) built from spare parts of the first space-borne SAR, SEASAT Mission in 1978 with improvements to the antenna and fixed-to-variable pointing capability. SIR-C flew dual C and X-frequency radars; the German and Italian Space Agencies jointly built the X-frequency radar. The missions proved that synthetic aperture radars flown on a space platform could under favorable conditions penetrate earth materials such as sand dunes of the Sahara and other deserts of Earth's middle latitudes. In particular the L-frequency radar had the capability to penetrate more than a meter depth at all combinations of send-receive polarization [4] [5] [6] [7].

During March 2004, we participated in a Global Positioning System data acquisition campaign on the frozen thaw lakes of the Barrow region of the North Slope, Alaska, confirmed the small error range less than $2 \mathrm{~cm}$ on a single-shot of the NASA Ice Cloud and land Elevation Satellite (ICESat) Geoscience Laser Altimeter System (GLAS) [8]. Our snow depth survey measurements on the frozen lakes have been well used in other research of snow thickness, density and snow water equivalent that are important environmental factors in the stability and vulnerability of the active layer and permafrost [9]. In research published in 2015 we compared ICESat GLAS elevation changes on locations of the North Slope to demonstrate by comparison and first principles that Advanced Land Observation Satellite (ALOS) Phased Array type L-band Synthetic Aperture Radar (PALSAR) line-of-sight changes on tundra landscapes in winter are composed more from volume scatter (snow, vegetation and sub-surface soil and the multi-path from each layer) than surface scatter (Figure 1) [10]. Furthermore, we gave direct evidence of the necessity of atmospheric (troposphere) corrections for space-borne Interferometric SAR (InSAR) on the North Slope due to the strong atmosphere affects from the seasonal variations of the Beaufort Gyre [10]. Other coastal regions with strong oceanographic gyres such as the Netherlands affect InSAR interferograms by tropospheric variations (including storm fronts) as demonstrated by Hanssen et al. [11]. Changes of the troposphere cannot be neglected [10]. Because the atmosphere is the first layer the high-altitude aircraft and spacecraft radar penetrates that can affect the optical path of multipass InSAR techniques such as incremental stacking of interferograms will only sum, not subtract, the changes of the troposphere. This makes high-altitude aircraft and spacecraft InSAR a wonderful operational weather monitoring system for regions without ground-based weather radar coverage [10]. For solid earth studies greater knowledge of the region's geology, hydrology, topography and vegetation are essential after the source of the tropospheric phase has been identified and mitigated [10].

In this paper we will review our research results using ICESat GLAS and AL- 
OS PALSAR measurements on tundra of the continuous permafrost zone, North Slope Alaska and present our new experiment to test the L-band SAR penetration depth on Arctic tundra (Figure 1).

\section{Data and Methods}

\subsection{Aircraft SAR Systems}

The aircraft systems we are utilizing consist of JPL NASA Airborne Microwave Observatory of Sub-canopy and Subsurface (AirMOSS, P-band), Uninhabited Aerial Vehicle Synthetic Aperture Radar (UAVSAR, L-band) and Glacier and Land Ice Surface Topography Interferometer-Airborne (GLISTIN-A, Ka-band) flown on the modified Gulfstream-III [12]. L-band SAR/InSAR datasets from AirMOSS and UAVSAR have spatial resolutions of $1.2 \mathrm{~m}$ (single polarization $\mathrm{HH}$ and $\mathrm{VV}$ ) is swaths of $12 \mathrm{~km}$ slant range from a maximum operating altitude of $13,700 \mathrm{~m}$. The JPL aircraft SAR systems are used to prototype future spacecraft SAR systems and to support current spacecraft SAR missions.

\subsection{Spacecraft SAR Systems}

The NASA ICESat mission was from January 2003 to October 2009 [10]. GLAS utilized three lasers each with a green $(532 \mathrm{~nm})$ and red $(1064 \mathrm{~nm})$ channel.

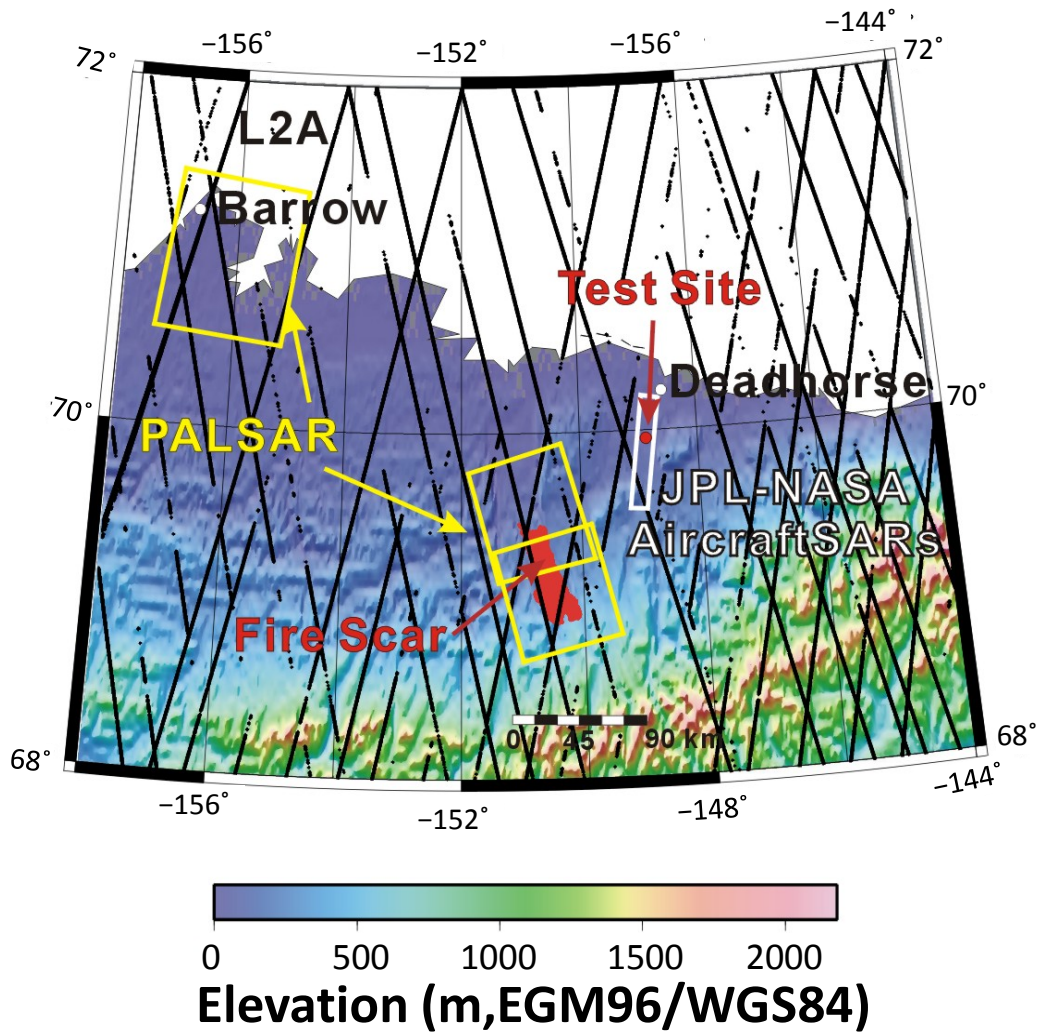

Figure 1. Study sites on the North Slope of Alaska. ICESat GLAS ground tracks from the L2A campaign are shown with ALOS PALSAR multi-pass InSAR on Barrow (a.k.a. Utqiagivik), Alaska and the Anaktuvuk River wildfire scar (2007) and JPLNASA aircraft multi-pass InSAR on our test site south of Deadhorse, Alaska. 
ICESat's $600 \mathrm{~km}$ altitude sun-synchronous polar orbit covered the Earth from $86^{\circ} \mathrm{N}$ to $86^{\circ} \mathrm{S}$ latitude in a period of 97 minutes, 14.8 orbits per day. Electronic deterioration of Laser 1 by mission-day 38 prompted of Lasers 2 and 3 into 30-day intervals within the original 91-day repeat cycle to mitigate degradation and continue the mission [10]. GLAS lasers pulsed at 40-times per second with a footprint diameter that varied from about $60 \mathrm{~m}$ to $70 \mathrm{~m}$ in a nominal-circular area [10]. Footprint centroid-to-centroid measured about $170 \mathrm{~m}$. Onboard special built JPL GPS (2) with dual-channel L-band channels, star-camera and retro-reflector cones provided for precise attitude, location, pointing and timing of the satellite and lasers [10]. Corrections to the GLAS data account for orbit, atmosphere and tides [10]. GLAS data are referenced to the International Terrestrial Reference Frame with vertical accuracy and precision better than $0.02 \mathrm{~m}$ [10].

The JAXA ALOS mission was from January 2006 to April 2011 [10]. ALOS orbited Earth from $82^{\circ} \mathrm{N}$ to $82^{\circ} \mathrm{S}$ latitude in a period of 99 minutes, 14.6 orbits per day [10]. Mission products for cartography, geodesy, environment and resource mapping at 1:25,000 scale called for $2.5 \mathrm{~m}$ horizontal resolution with 3 to $5 \mathrm{~m}$ vertical accuracy [10]. The ALOS PALSAR operated with full polarization $\mathrm{HH}$ VV and cross-polarization HV VH modes, dual polarization $\mathrm{HH}+\mathrm{HV}$ and $\mathrm{VV}+\mathrm{VH}$ and quad-polarization modes [10], Ground resolution varied from nominal $10 \mathrm{~m}$ in range and azimuth to nominal $20 \mathrm{~m}$ in range and $10 \mathrm{~m}$ in azimuth [10]. Geolocation accuracy was 3 to $7.5 \mathrm{~m}$. Multi-pass InSAR Line Of Sight (LOS) absolute accuracy was validated at $74 \mathrm{~mm} \mathrm{[10].}$

JAXA in May 2014 launched the follow-on mission ALOS2 PALSAR2 [13]. PALSAR2 has improvements to the SAR antenna (structure and left-right aiming) and electronics.ALOS2 has improved GNSS (dual-receiver and dual-channel) for greater accuracy and precision and 14-day revisit orbit. In addition to the JAXA L-band SAR datasets we are incorporating ESA Sentinel $1 \mathrm{~A}$ and $1 \mathrm{~B}$ C-band SAR datasets for collocated C- and L-band terrestrial radio frequency interference analysis [14].

\subsection{Test Site Ground Measurement Systems}

Our experiment test site is instrumented for measuring ground elevation and environmental parameters with their temporal variations during the three-year project. For elevation reference and changes we employ Topcon Global Navigation System of Systems (GNSS) instruments using both GPS and GLONASS L-band radio signals deployed at the test site. We utilize NOAA Continuously Operating Receiver Systems for network-based least square solutions to local receiver position $(x, y, z, t)$ with respect to the International Terrestrial Reference Frame in Alaska. Environmental parameters of surface temperature, relative humidity, wind speed and snow thickness with subsurface temperatures at three depths with soil moisture and dielectric constants are measured by ONSET and Stevens HydroProbe II sensors with solar (summer) and battery (winter) dataloggers. 


\section{Review of Spacecraft InSAR Results}

\subsection{Troposphere Phase, Barrow Alaska}

Figure 2 shows the ALOS PALSAR granule-pairs LOS change maps at the ALOS overpass times rendering 94-day and 47-day repeat intervals on the Barrow region, Alaska [10]. The topographic phase is removed leaving residual phase at the overpass intervals as LOS change maps [10]. Using ICESat GLAS exact repeat profiles in the period of the ALOS overpass time we validated the surface elevation changes (snow thickness) and coastal-river ice-covered low-tide using NOAA Barrow-Offshore station (\#9494935) data for 12 December 2008 [10]. Tide variation measurements by ICESat GLAS have been analyzed and reported for the ice-covered channels of the Lena Delta and near-shore ice-cover of the Laptev Sea [15].

20070806 to 20071106
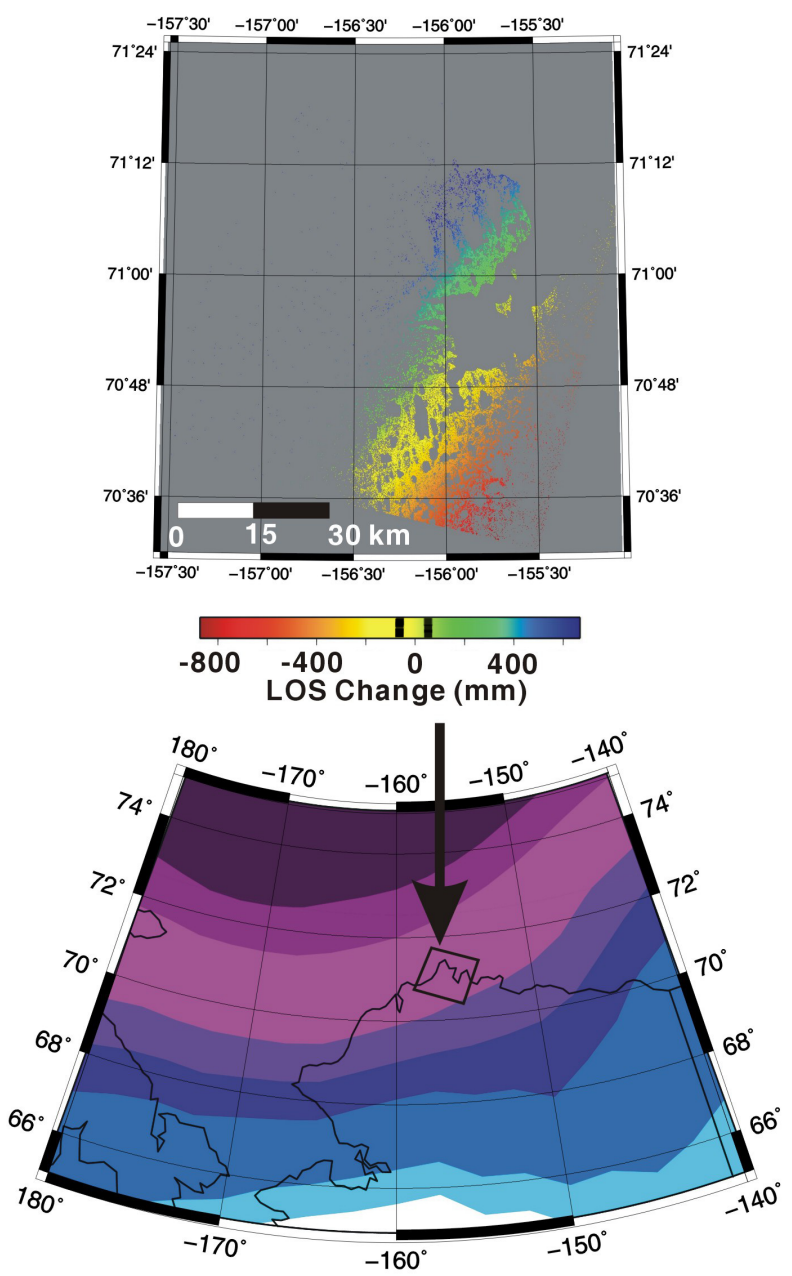

94-Day Tropopause Pressure Anomaly (mb)
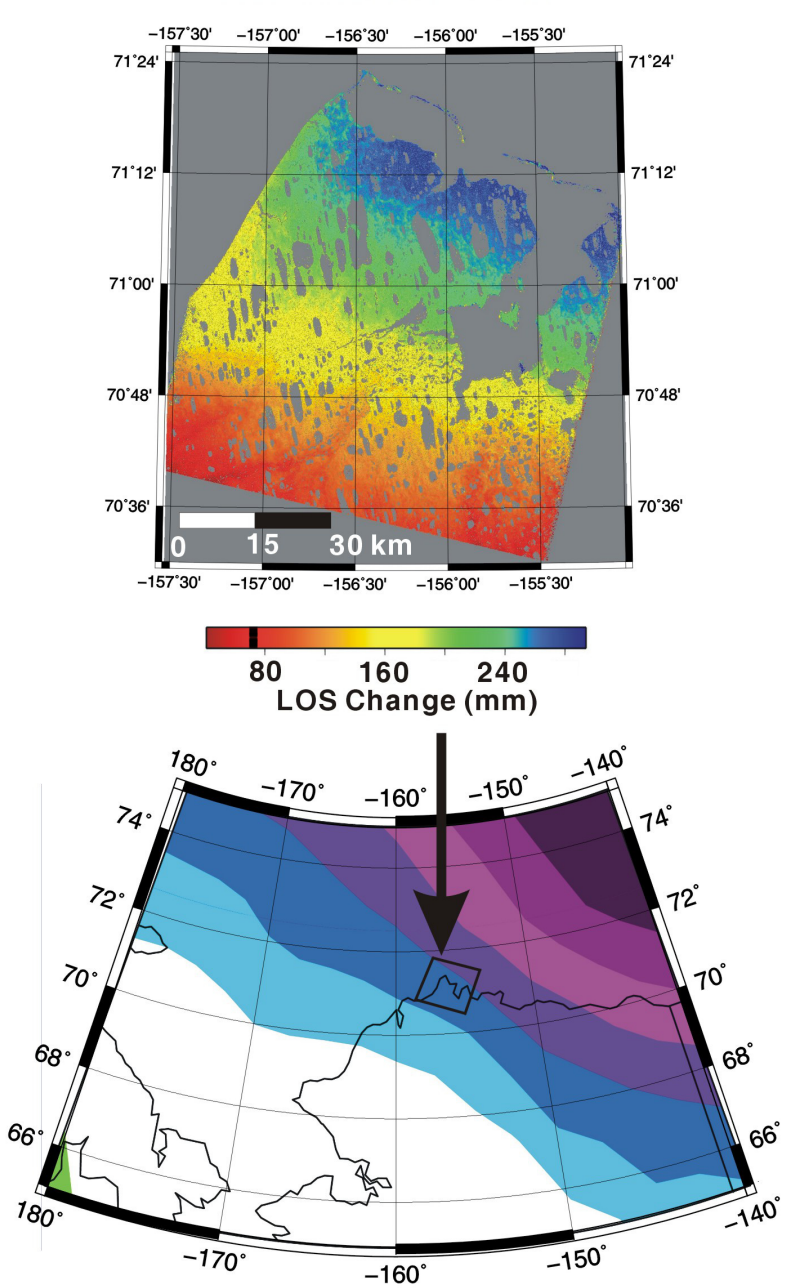

47-Day Tropopause Pressure Anomaly (mb)

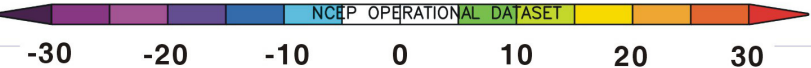

Figure 2. Examples of L-band InSAR troposphere phase gradients whose source is the anomaly of the tropopause pressure field at the time of the spacecraft overpasses, i.e. optical path changes [10]. Black bars on thetop LOS scales give the LOS error range: \pm 74 $\mathrm{mm}[10]$. 
The LOS change maps gradient orientations change with the overpass interval times. The 94-day LOS change map shows the gradient oriented relative to the northwest, Chukchi Sea coast [10]. The 47-day LOS change map shows the gradient oriented northeast to the Beaufort Sea coast. NCEP reanalysis of the tropopause pressure field $(\mathrm{mb})$ shows the anomaly in tropopause pressure (i.e. pressure change also correlated with atmospheric water vapor) at the dates of the ALOS PALSAR granule-pairs. Phase and LOS change gradients have been derived before using ERS Tandem Mission SAR data for InSAR processing of digital elevation models [8]. The LOS gradients are an expression of tropopause pressure changes [9]. Troposphere pressure field, atmospheric moisture and wind fields and their seasonal non-stationary variations are an expression of the Beaufort Gyre [16]. Troposphere pressure, water vapor and temperature variations serve to alter the optical path of the radar at the overpass times [5] [8] [10]. The presence of coherent short-period tropospheric phase has to be accounted for before any interpretation (i.e. heave and subsidence) of surface deformation. Unfortunately many previous studies ignored error and troposphere phase rendering their interpretations of surface subsidence as meaningless [17] [18] [19] [20]. X-band InSAR (Terrsar-X Tandem-X) has LOS error of 10 to $141 \mathrm{~mm}$ [21].

\subsection{Anaktuvuk River Wildfire Scar, Alaska}

Wildfires are a growing concern for Alaska and elsewhere across Arctic landscapes. Wildfires in Alaska like those in Siberia have both local effects to the environment and by release of aerosols and long-range transport of smoke plumbs by wind currents across the hemisphere. The largest recorded wildfire on the tundra permafrost landscape of the Anaktuvuk River area began in July 2007 (Figure 3). This fire burned more than $27,000 \mathrm{~km}^{2}$. Post-fire effects within the burn scar include vegetation succession [10].

Inside the fire scar change is too large for ALOS PALSAR to measure, i.e. incoherent. Yet, outside the fire scar are many examples where coherence is high and LOS change exceeds error in the form of surface heave not subsidence in the four-year repeat period (Figure 3). The pingos (ice-cored mounds, p1 - 5) are well studied and serve as natural benchmarks for geolocation and vertical-scale accuracy and precision assessments that show no changes in excess of error, i.e. stable [10].

Outside the fire scar changes are coherent and evident by 2015 (Figure 3) [10]. ALOS PALSAR LOS change values on river gravel bars (radar hard targets) are above error (in excess of $74 \mathrm{~mm}$ ) [10]. They show that rivers on the east and west of the scar experienced erosion (LOS+) and deposition (LOS-). The tundra (radar soft targets, attenuation and volume scattering) shows both low coherence and LOS changes within error and sub-regions with high coherence and LOS changes in excess of error indicating both surface heave and subsidence [10].

During the overlapping measurement periods ICESat GLAS elevation change shows the variations of surface scattering by snow thickness climatology whereas the ALOS PALSAR LOS change shows the convolved variations of snow, soil 


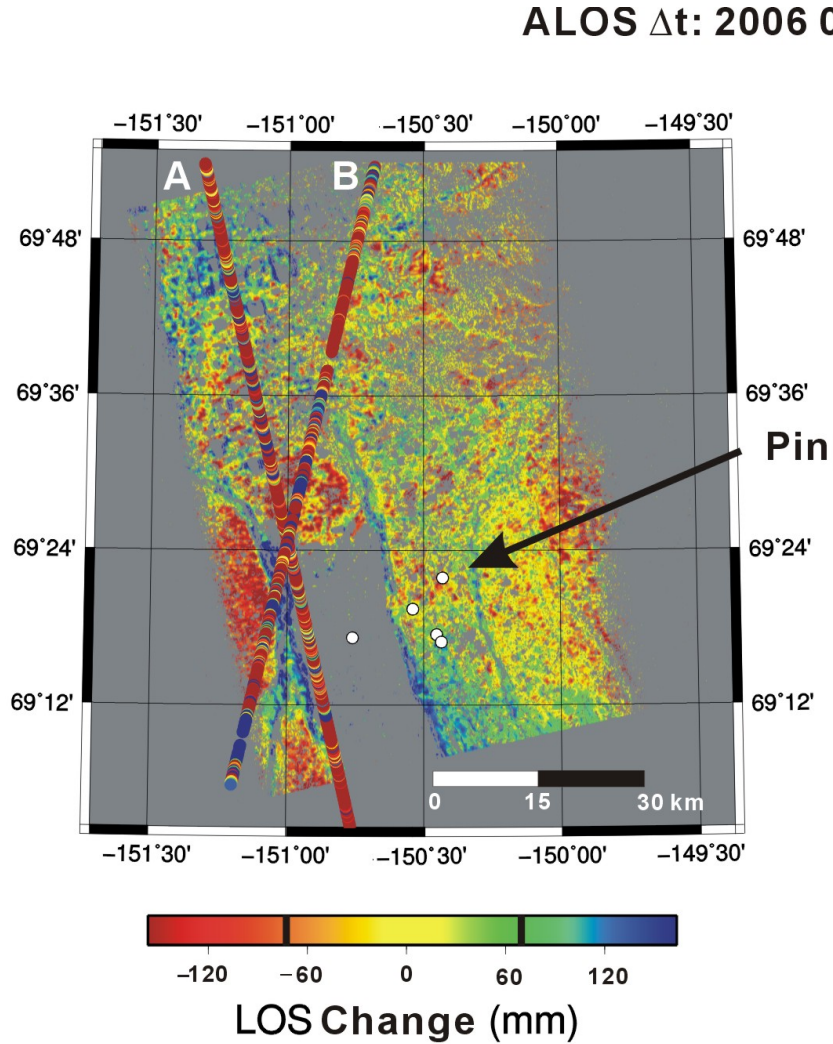

\section{A ICESat $\Delta t: 20031027$ to 20060305 \\ B ICESat $\wedge t: 20061115$ to 20070402}

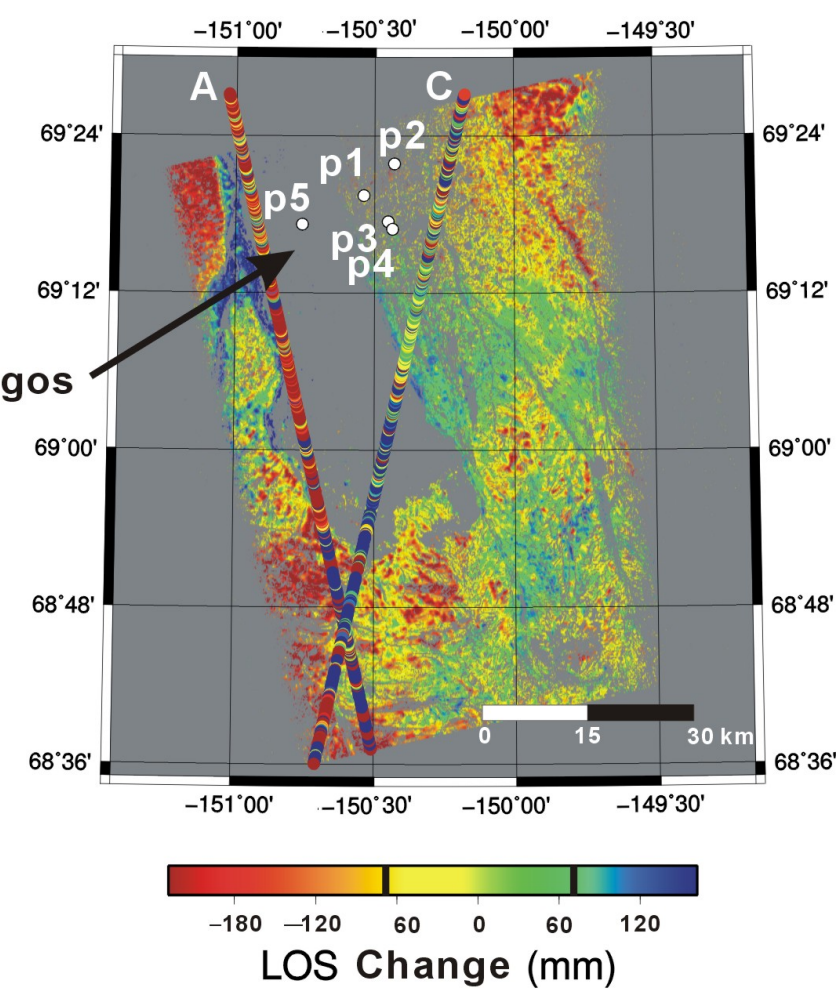

\section{A ICESat $\Delta t: 20031027$ to 20060305 \\ C ICESat $\wedge t$ : 20031114 to 20061123}

Figure 3. ALOS PALSAR Ling-Of-Sight (LOS) changes and ICESat GLAS elevation differences (pre-wildfire, re-cast as LOS change) on the Anaktuvuk River area [10]. The wildfire scar is the incoherent area containing pingo p5. Black bars on the scale give the LOS error range: $\pm 74 \mathrm{~mm}$.

and vegetation volume scattering attenuation (Figure 4) [10]. The blue-dashed line is the mean elevation difference and validated from snow thickness (increase) using met-stations at Franklin Bluffs and Umiat [10].

\section{L-Band InSAR Penetration Depth Experiment on Arctic Tundra, Alaska}

This year we are performing a series of quantitative experiments at a site on the North Slope, Alaska, to test aircraft and spacecraft L-band SAR/InSAR penetrative abilities on tundra using a multi-frequency approach with successive burial of radar reflective elements (Figure 5). The aircraft systems we are utilizing consist of JPL NASA AirMOSS (P-band), UAVSAR, L-band and the Glacier and Land Ice Surface Topography Interferometer-Airborne (GLISTIN-A, Ka-band) flown on the modified Gulfstream-III. The spacecraft systems consist of the ESA Sentinel 1A and 1B satellite C-band and the JAXA ALOS2 POLSAR2. Each of the aircraft and spacecraft systems gives SAR data in polarizations at $\mathrm{HH}, \mathrm{VV}$, HV and VH. Global Navigation System of Systems (GNSS) instruments using both GPS and GLONASS L-band radio signals deployed at the test site establishes 


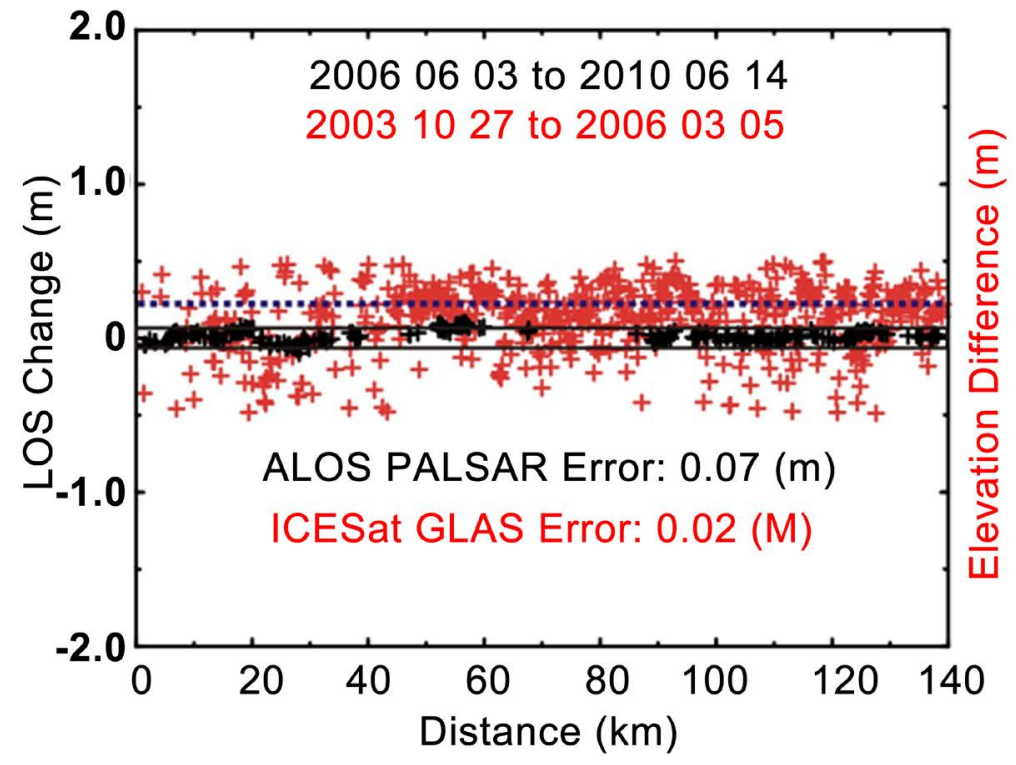

Figure 4. ColocatedICESat GLAS elevation difference (i.e. change) and ALOS PALSAR LOS change, track-A in Figure 3 [10]. The blue dashed line is the mean elevation difference along the ICESat GLAS track, correlated to snow thickness change at Franklin Bluffs and Umiat met-stations.Error range of ALOS PALSAR $( \pm 74 \mathrm{~mm})$ is given and shown by the black solid lines. ICESat GLAS error range $( \pm 15 \mathrm{~mm})$ is given.

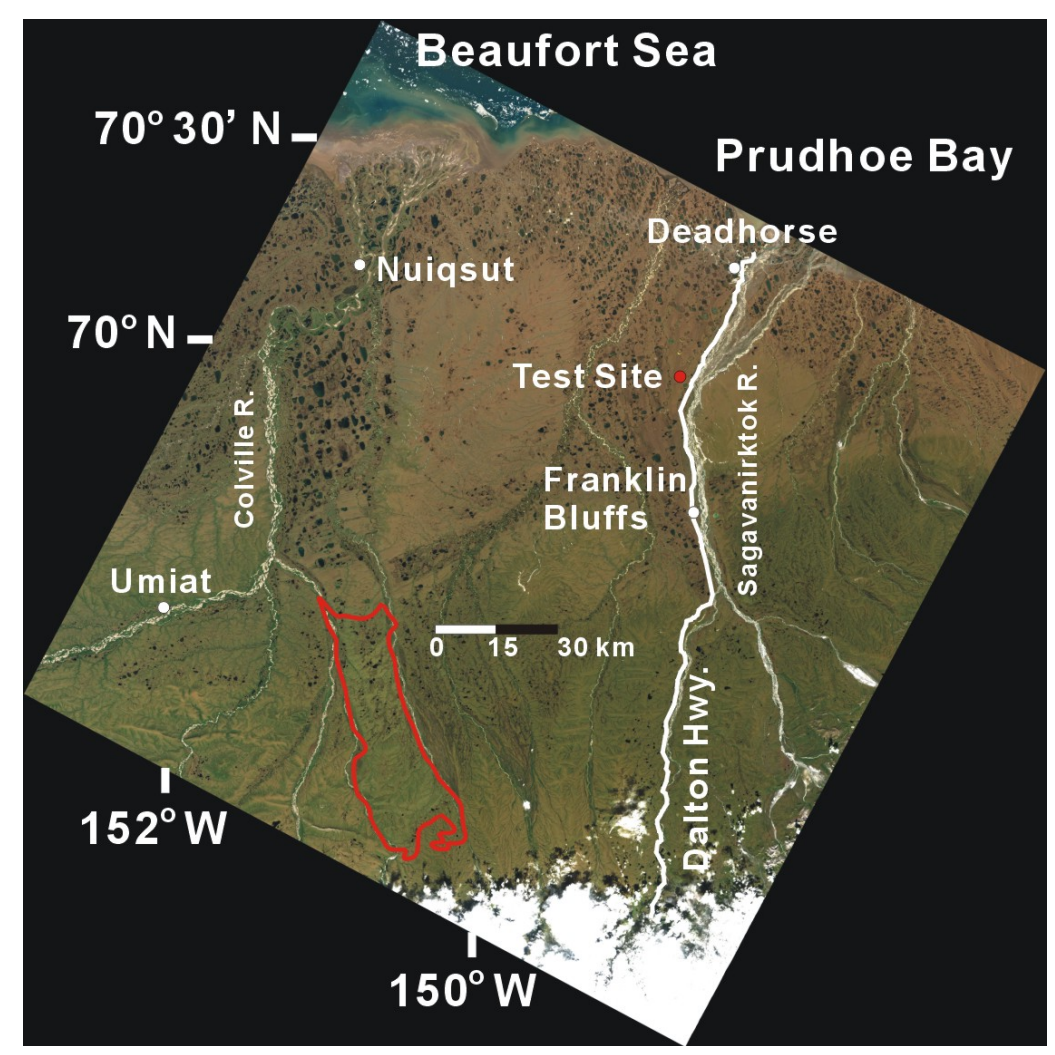

Figure 5. North Slope, Alaska, south of Beaufort Sea and Prudhoe Bay (USGS Landsat 8 image). The proposed the proposed experiment test site (red dot) between Permafrost Observatory sites Deadhorse and Franklin Bluffs. The red outline shows the area of the 2007 wildfirethat is now recovered. 
the most accurate elevation reference by utilizing network of NOAA Continuously Operating Receiver Systems with the International Terrestrial Reference Frame in Alaska.

The test site (Figure 5 and Figure 6) consisting of upland well-drained to moist unconsolidated silts-sands-gravels above the Gubik and Sagavanirktok
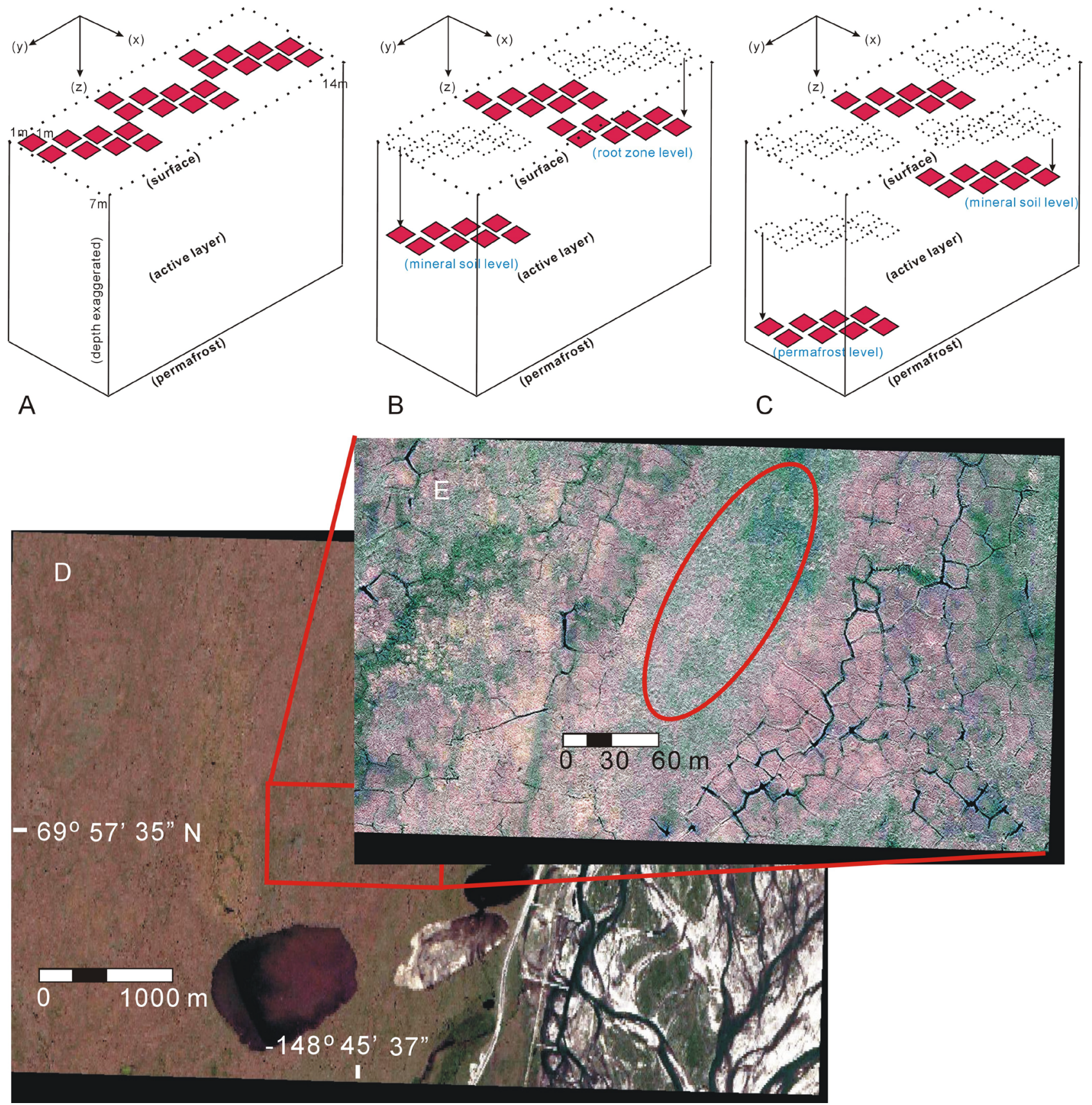

Figure 6. Test site radar reflective meshes ( $1 \mathrm{~m}$ squares, red) and geometric pattern on the tundra (vertical depth is exaggerated). $(\mathrm{x}),(\mathrm{y})$ and $(\mathrm{z})$ are local coordinate system in relative Southeast, Southwest and Depth, respectively. During the experiment years (A), (B) and (C) meshes are initially placed directly on the tundra (A) are lowered progressively deeper (B) and (C) for the SAR acquisitions by aircraft and spacecraft. The orientation of the geometry will be such that we maximize the overpassing airborne and spaceborneSAR range and azimuth ground resolutions. Inset Worldview 3 (D), (E) shows close-up details of the test site (red-oval in E) where ice-wedge networks are to be avoide. 
Formations and vegetation cover of sedge-shrub-tussock tundra will be instrumented with autonomous digital recording devices for snow thickness, soil moisture and temperature, and soil dielectric constants adjacent to the radar reflectors [22] [23] [24]. The site is situated between emergent ice-wedge networks. The thermistors are deployed at depths of the root zone, mineral soil and permafrost-active layer interface [9] [14]. Snow thickness, relative humidity and air temperature sensors are mounted on a tri-pod and secured to the tundra by anchors give us measurements of the surface environment and changes during the project. Data recording is accomplished using a data logger powered by battery (cloudy and winter conditions) and solar panel (summer) mounted to the anchored tri-pod.

\section{Radar Mesh Reflectors}

A measure of radar backscatter strength is the radar cross section (RCS). The $\operatorname{RCS}\left(\mathrm{dB} \mathrm{m}^{2}\right)$ of a square plane (hedral) reflector is $4 \pi 1^{4} / \lambda^{2}$ [25]. In our case 1 is the length of a mesh-side $(1 \mathrm{~m})$ and $\lambda$ is the wavelength of the radar $(0.24 \mathrm{~m}$ for L-band). This gives an RCS of $23.4 \mathrm{~dB} \mathrm{~m}^{2}$. The backscatter-response spread from a solid plane has one elongated center lob aligned to the normal of the plane and very small side lobes. This would necessitate the overpassing airborne-SAR to be oriented to the nadir to receive a signal response at the maximum RSC. Using a wire mesh introduces half-spherical 2D-geometric elements into the area of the plane that serve to amplify and spread (broaden) the backscatter signal response, Figure 7. This allows for overpasses of the aircraft and spacecraft SAR in side-look geometry, as is the design for JPL-NASA AirMOSS and JAXA PALSAR2 for example, to receive an enhanced signal at $45^{\circ}$ to the nadir. The InSAR range resolution (L-band) is $1.8 \mathrm{~m}$ (perpendicular to flight direction) and azimuth is $0.8 \mathrm{~m}$ (along flight direction).

In theory as the mesh reflectors are buried the backscatter signal strength will diminish relative to the backscatter strength of the reflectors on the tundra as well as to the background response of the tundra. The lowest level of burial where the backscatter signal strength becomes equivalent to the background tundra signal, about -16 to $-18 \mathrm{~dB}$, is when the penetration depth is reached.

One of the first attempts to use airborne Side-Looking Radar (X-band) was by the personnel of the US Army Cold Regions Research and Engineering Laboratory (CRREL) in experiments conducted in April-May 1974 on a region of Barrow to Teshekpuk Lake, North Slope, Alaska [26]. In this study qualitative results of backscatter strength pointed to the radar penetrating frozen lake ice cover in some cases to the lake bed. Jefferies et al. [27] examined this effect using the European Space Agency Earth Resources Satellite-1 (ERS-1) radar backscatter temporal changes on the freezing of the oriented thaw lakes of the Barrow, Alaska region. Duguay and Lafleur [28] derived a shallow (1 to $2 \mathrm{~m}$ ) lake bathymetry map (LANDSAT Enhanced Thematic Mapper and ground-data) with sequential ERS-1 to demonstrate C-band radar backscatter temporal variations successfully determined lake-depth with ice freeze-on to the bed (Figure 8). As 

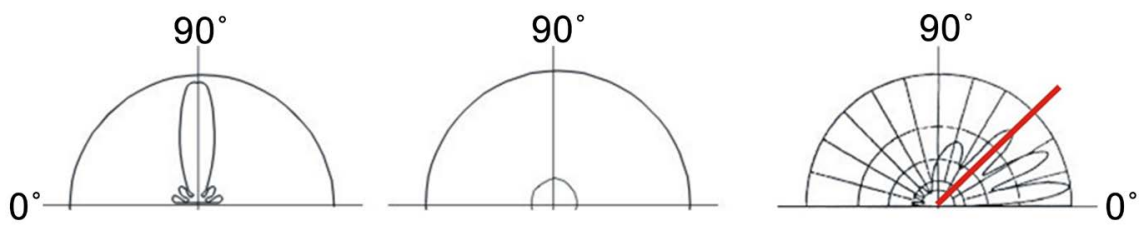

FLAT PLATE

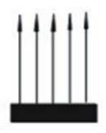

SPHERE

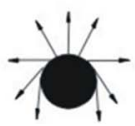

MESH

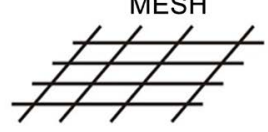

Figure 7. Relative backscatter radiation patterns due to the construction of simple geometric reflecting elements (adapted from [25]). Redline on the mesh radiation pattern indicates an optimum look-angle dependent on mesh spacing for a side-looking SAR.

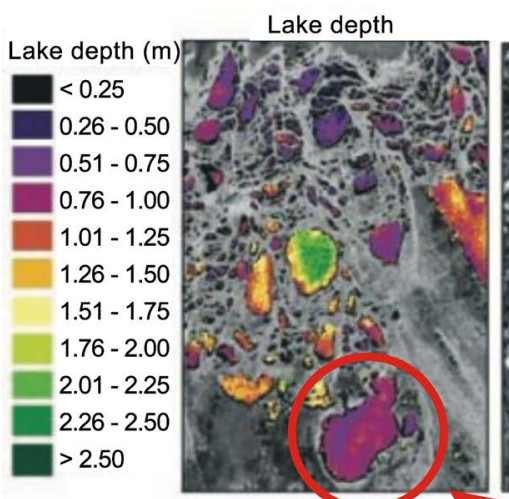

19 February 1993

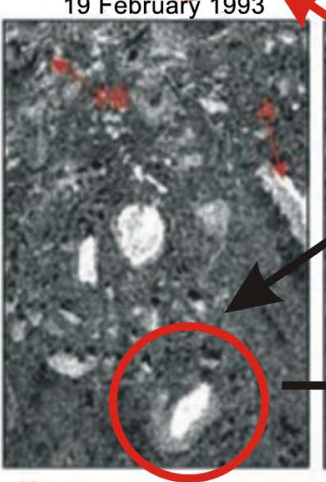

$5 \mathrm{~km}$
11 December 1992
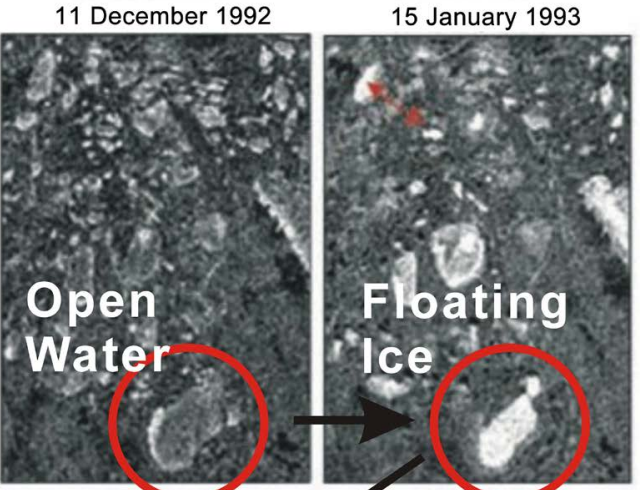

30 April 1993

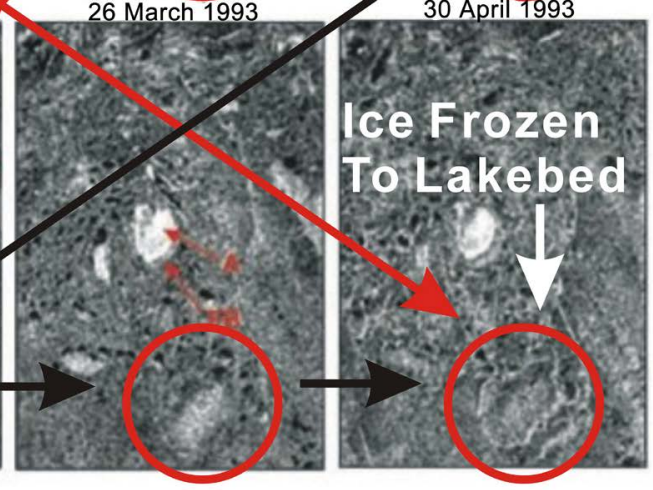

Figure 8. Example of winter ERS-1 (C-band) radar backscatter changes of shallow lake ice cover and bed freeze-on modified from [28]. See [28] for the analysis and correlation of sigma-0 values in dBto ice freeze-on to lakebed depth and date as illustrated. Temporal evolution of the backscatter illustrated by black arrows and red arrow shows C-band SAR backscatter at the date of ice freeze-on to the bed at lake depth, i.e. C-band SAR penetration through lake ice.

the lake water freezes, ice crystals with bubbles (mixtures of $\mathrm{O}_{2}, \mathrm{CO}_{2}$ and $\mathrm{CH}_{4}$ ) orient as vertical trails and preferentially interact with the incident radar (Cband in this case) to produce relatively bright backscatter of about $-4 \mathrm{~dB}$. As the water at depth continues to freeze from the top-down the radar backscatter 
gradually lowers in value. When the ice intersects and freezes to the lake bottom the dielectric contrast of the radar at the ice-water interface is lost and the backscatter assumes the background value of the surrounding tundra.

The methodology of our test is to use radar-reflective meshes buried at measured depths below the tundra to the permafrost level (the active layer) to simulate the effect noted by Sellmann et al. [26], Jefferies et al. [27] and Duguay and Lafleur [28], and thereby measure the penetration depth of the airborne L-band InSAR. The reference of these measurements is relative to reference elevation ITRF EPOCH 2015 (EMG96/WGS 84) using GNSS receiver's multi-channel collocated in Real-Time Kinematic (RTK) and Differential GNSS with the NGANSF ArcticDEM and USGS Alaska 5 m DEM [29] [30].

\section{Discussion}

Permafrost, i.e. perennially frozen ground covers much of the northern and southern hemispheres is categorized as continuous, discontinuous and sporadic zones [31] [32]. Permafrost can be dry and composed of rock and soil and typically a high content of organic matter. Influx of seasonal moisture can lead to the presence of ice such as massive ground ice and ice-wedge networks. Since the Last Glacial Maximum and the Younger Dryas-Pre-Boreal Transition patterned ground landscapes with networks of high and low centered polygons became present. This occurred following the loss of the Laurentide and Scandinavian ice sheets and reduction of the permafrost area since LGM [31].

Above perennially frozen ground is the active-layer of seasonal thawing. Where ice content of permafrost is volumetrically high seasonal melting and refreezing of ice can lead to small motions at millimeter to centimeter scales of the ground surface as ice-wedges grow or degrade and polygon interior-surfaces change from high to low and vice versa over a period of years [31]. Measuring the vertical motions of the patterned-ground of such small-scale and understanding the causes and feedbacks is an ongoing part of permafrost research [32]. These small-scale surface displacements can be measured accurately with very simple methods [33]. Scientists are now seeking answers as to how these patterns of surface changes can affect regional carbon, energy and water cycles. Therefore, a growing challenge is to perform a measuring process with the same accuracy as traditional methods and that can cover permafrost landscapes at the regional scale for assessment of linked forcing and feedback of recent and longterm changes of climatology [34].

Radar penetration depth on Arctic tundra (lowland continuous permafrost zone) is needed by biologists and ecologists, engineers, and geologists and geophysicists studying the gradual year-to-year and decadal changes of the active layer, ground ice, ice-wedge networks and permafrost at depth. This information is vital to practical engineering for commerce and industry activity as well to support science objectives in Biology and Ecology, Geology and Geophysics, Hydrology and Meteorology. Knowledge of current ice-wedge networks, both high and low-center polygons and their changes over multi-year to decadal time 
and effects from temporary human habitation is vital [35]. We must measure millimeter level changes at sufficient accuracy and precision to improve estimates of the changes in carbon storage that portend large positive feedback to the Earth's climate system and land vegetation on decadal to centennial time scales and can adversely affect the stability of the Earth's permafrost periglacial regions [36] [37].

Quantitatively demonstrating that airborne L-band InSAR penetrates the tundra to the depth of permafrost (active layer depth) in the continuous zone (the hypothesis we evaluate) will be a first of its kind of measurement and give many the means to remotely measure the permafrost depth over large expanses of terrain of the northern hemisphere and elsewhere. This would be a monumental improvement over our monitoring capabilities at present with networks of point stations scattered by 1000s of kilometers in distance. Ground networks such as Global Thematic Network for Permafrost (GTN-P) of point-wise stations become the control networks for areal InSAR operations with the continuously operating GNSS stations, NOAA CORS, of the International Terrestrial Reference Frame [38]. At the conclusion of Project INSAR A-TEAM the test site will be re-furbished for inclusion to the GTN-P and readied for future aircraft and spacecraft-based SAR and InSAR activities to meet objectives of providing information for sensor development and monitoring the continuing changes of the Arctic's periglacial active layer and permafrost.

InSAR geodetic reconnaissance by aircraft and spacecraft is a critical technique to assess the Arctic permafrost regions for changes of biology, ecosystem, geology, hydrology, meteorology and the impacts and feedbacks from changes in Arctic climate. In the high-latitude lowland permafrost zones of Eurasia and North America particular attention to troposphere and ionosphere phases and their manifestations in the LOS change maps must be accounted for before interpretations of active-layer and permafrost (heave and subsidence) can be obtained. Neglecting an absolute reference frame, ignoring error and uncertainty, not accounting for loss of accuracy and precision, not knowing the depth of penetration and falsely assuming that the atmosphere phases have no effect on the optical path of the radar used whether L-, C-, X- or Ka-frequency has led to many unfortunate interpretations that need to be corrected.

\section{Conclusion}

Aircraft and Spacecraft SAR/InSAR systems can provide needed and timely measurements and observations of meteorological phenomena and local weather events in the Arctic where ground-based civilian radar systems are few and widely dispersed. Investigators of solid-earth deformation phenomena in the Arctic need to pay attention to the atmospheric effects on InSAR by aircraft and spacecraft multi-pass operations. Radar has the capability to penetrate earth materials at frequencies from the P- to X-band. Therefore attention must be given to the frequency dependent penetration depth and volume scattering, in particular L-band SAR/InSAR. We are performing a test of the SAR/InSARL-band 
depth of penetration of tundra at a site on the North Slope of Alaska using multi-frequency and multi-pass aircraft and spacecraft SAR/InSAR systems. The L-band penetration depth on lowland Arctic tundra is a necessary parameter to constrain analysis of carbon mass balance and hazardous conditions arising from permafrost degradation and thaw, surface heave and subsidence and thermokarst formation at local and regional scales.

\section{Acknowledgements}

We thank the Jet Propulsion Laboratory, California Institute of Technology, NASA programs and facilities including the Arctic-Boreal Vulnerability Experiment, Earth Airborne Science Program, NASA-India SAR mission, Ames Research Center, Armstrong Flight Center and Goddard Space Flight Center. We thank the Department of Energy Next Generation Ecosystem Experiment. We thank the Japanese Space Exploration Agency Earth Observation Center. We thank the State of Alaska, the National Geospatial-Intelligence Agency DOD, the National Science Foundation and the US Department of Interior. We thank Vladimir E. Romanovsky Geophysical Institute University of Alaska Fairbanks.

\section{References}

[1] Elachi, C., Brown, W.E., Cimino, J.B., Dixon, T., Evans, D.L., Ford, J.P., Saunders, R.S., Breed, C., Masursky, H., Mccauley, J.F., Schaber, G., Dellwig, L., England, A., Macdonald, H., Martin-Kaye, P. and Sabins, F. (1982) Shuttle Imaging Radar Experiment. Science, 218, 996-1003. https://doi.org/10.1126/science.218.4576.996

[2] Elachi, C., Cimino, J. and Settle, M. (1986) Overview of the Shuttle Imaging Radar-B Preliminary Scientific Results. Science, 232, 1511-1516. https://doi.org/10.1126/science.232.4757.1511

[3] Stofan, E.R., Evans, D.L., Schmullius, C., Holt, B., Plaut, J.J., von Zyl, J., Wall, S.D. and Way, J. (1995) Overview of Results of Spaceborne Imaging Radar-C, X-Band Synthetic Aperture Radar (SIR-C/X-SAR). IEEE Transactions on Geoscience and Remote Sensing, 33, 817-828. https://doi.org/10.1109/36.406668

[4] McCauley, J.F., Schaber, G.G., Breed, C.S., Grolier, M.J., Haynes, C.V., Issawi, B., Elachi, C. and Blom, R. (1982) Subsurface Valleys and Geoarchaeology of the Eastern Sahara Revealed by Shuttle Imaging Radar. Science, 218, 1004-1020. https://doi.org/10.1126/science.218.4576.1004

[5] Schaber, G.G., McCauley, J.F., Breed, C.S. and Olhoeft, G.R. (1986) Shuttle Imaging Radar: Physical Controls on Signal Penetration and Subsurface Scattering in the Eastern Sahara. IEEE Transactions on Geoscience and Remote Sensing, GE-24, 603-623. https://doi.org/10.1109/TGRS.1986.289677

[6] Schaber, G.G., McCauley, J.F. and Breed, C.S. (1997) The Use of Multifrequency and Polarimetric SIR-C/X-SAR Data in Geologic Studies of BirSafsaf, Egypt. Remote Sensing of Environment, GE-59, 337-363. https://doi.org/10.1016/S0034-4257(96)00143-5

[7] Schaber, G.G. and Breed, C.S. (1999) The Importance of SAR Wavelength in Penetrating Blow Sand in Northern Arizona. Remote Sensing of Environment, 68, 87104. https://doi.org/10.1016/S0034-4257(99)00013-9

[8] Atwood, D.K., Guritz, R.M., Muskett, R.R., Lingle, C.S., Sauber, J.M. and Freymueller, J.T. (2007) DEM Control in Arctic Alaska with ICESat Laser Altimetry. IEEE 
Transactions on Geoscience and Remote Sensing, 45, 3710-3720. https://doi.org/10.1109/TGRS.2007.904335

[9] Muskett, R.R. (2012) Remote Sensing, Model-Derived and Ground Measurements of Snow Water Equivalent and Snow Density in Alaska. International Journal of Geosciences, 3, 1127-1136. https://doi.org/10.4236/ijg.2012.35114

[10] Muskett, R.R. (2015) ICESat GLAS Elevation Changes and ALOS PALSAR InSAR Line-of-Sight Changes on the Continuous Permafrost Zone of the North Slope, Alaska. International Journal of Geosciences, 6, 1101-1115. https://doi.org/10.4236/ijg.2015.610086

[11] Hanssen, R.F., Weckwerth, T.M., Zebker, H.A. and Klees, R. (1999) High-Resolution Water Vapor Mapping from Interferometric Radar Measurements. Science, 283, 1297-1299. https://doi.org/10.1126/science.283.5406.1297

[12] https://airbornescience.nasa.gov/

[13] https://directory.eoportal.org/web/eoportal/satellite-missions/a/alos-2

[14] Muskett, R.R., Romanovsky, V.E., Cable, W.L. and Kholodov, A.L. (2015) Active-Layer Soil Moisture Content Regional Variations in Alaska and Russia by Ground-Based and Satellite-Based Methods, 2002 through 2014. International Journal of Geosciences, 6, 12-41. https://doi.org/10.4236/ijg.2015.61002

[15] Muskett, R.R. (2014) ICESat-Derived Elevation Changes on the Lena Delta and Laptev Sea, Siberia. Open Journal of Modern Hydrology, 4, 1-9. https://doi.org/10.4236/ojmh.2014.41001

[16] Asplin, M.G., Lukovich, J.V. and Barber, D.G. (2009) Atmospheric Forcing of the Beaufort Sea Ice Gyre: Surface Pressure Climatology and Sea Ice Motion. Journal of Geophysical Research, 114, C00A06. https://doi.org/10.1029/2008jc005127

[17] Liu, L., Zhang, T. and Wahr, J. (2010) InSAR Measurements of Surface Deformation over Permafrost on the North Slope of Alaska. Journal of Geophysical Research, 115, F03023.

[18] Liu, L., Schaefer, K., Zhang, T. and Wahr, J. (2012) Estimating 1992-2000 Average Active Layer Thickness on the Alaskan North Slope from Remotely Sensed Surface Subsidence. Journal of Geophysical Research, 117, F01005.

https://doi.org/10.1029/2011jf002041

[19] Liu, L., Jafarov, E.E., Schaefer, K.M., Jones, B.M., Zebker, H.A., Williams, C.A., Rogan, J. and Zhang, T. (2014) InSAR Detects Increase in Surface Subsidence Caused by an Arctic Tundra Fire. Geophysical Research Letters, 41, 3906-3913. https://doi.org/10.1002/2014GL060533

[20] Iwahana, G., Uchida, M., Liu, L., Gong, W., Meyer, F., Guritz, R., Yamanokuchi, T. and Hinzman, L. (2016) InSAR Detection and Field Evidence for Thermokarst after a Tundra Wildfire, Using ALOS-PALSAR. Remote Sensing, 8, 218. https://doi.org/10.3390/rs8030218

[21] Fritz, T., Rossi, C., Yague-Martinez, N., Rodriguez-Gonzalez, F., Lachaise, M. and Breit, H. (2011) Interferometric Processing of TanDEM-X Data. IEEE Geoscience and Remote Sensing Symposium, Vancouver, 24-29 July 2011, 2428-2431. https://doi.org/10.1109/igarss.2011.6049701

[22] Acevedo, W., Walker, D., Gaydos, L. and Wray, J. (1982) Vegetation and Land Cover Arctic National Wildlife Refuge Coastal Plain, Alaska. US Geological Survey, Miscellaneous Investigation Series, MAP I-1443.

[23] Walker, D.A. (1985) Vegetation and Environmental Gradients of the Prudhoe Bay Region, Alaska. CRREL Report 85-14.

[24] Rawlinson, S.E. (1990) Surficial Geology and Morphology of the Alaskan Central 
Arctic Coastal Plain. Alaska Division of Geological \& Geophysical Surveys Public Data File 90-27. https://doi.org/10.14509/1461

[25] Avionics Department, Electronic Warfare and Radar Systems Engineering Handbook (Unclassified) (2013) NAWCWD Technical Publication 8347. 4th Edition, Naval Air Warfare Center Weapons Division, Point Mugu.

[26] Sellmann, P., Weeks, W.F. and Campbell, W.J. (1975) User of Side-Looking Airborne Radar to Determine Lake Depth on the Alaskan North Slope. US Army, Corps of Engineers, Cold Regions Research and Engineering Laboratory, and the Water Resources Division, US Geological Survey, CRREL Special Report 230.

[27] Jefferies, M.O., Morris, K., Weeks, W.F. and Wakabayashi, H. (1994) Structural and Stratigraphic Features and ERS 1 Synthetic Apertureradar Backscatter Characteristics of Ice Growing on Shallow Lakes in NW Alaska, Winter 1991-1992. Journal of Geophysical Research, 99, 22459-22471. https://doi.org/10.1029/94JC01479

[28] Duguay, C.R. and Lafleur, P.M. (2003) Determining Depth and Ice Thickness of Shallow Sub-Arctic Lakes Using Space-Borne Optical and SAR Data. International Journal of Remote Sensing, 24, 475-489. https://doi.org/10.1080/01431160304992

[29] NSF (2015) National Geospatial-Intelligence Agency Support Development of New Arctic Maps. Press-Release 15-099, Arlington.

[30] Morin, P., Porter, C., Cloutier, M., Howat, I., Noh, M.-J., Willis, M., Bates, B., Willamson, C. and Peterman, K. (2016) A Publically Available, High Resolution Elevation Model of the Arctic. Geophysical Research Abstracts 18, EGU2016-8396.

[31] Constantinova, G.S. (1978) Permafrost Landscape, 133-135 in Permafrost. 2nd International Conference, Washington DC, 13-28 July 1973, Document Page Count 783.

[32] Scheffers, A.M., May, S.M. and Kelletat, D.H. (2015) Chapter 13: Frost and Permafrost as Morphological Agents (Or the Perglacial Domain). In: Scheffers, A.M., May, S.M. and Kelletat, D.H., Eds., Landforms of the World with Google Earth: Understanding Our Environment, Springer, Dordrecht, 347-374.

[33] Slaymaker, O. and Kelly, R.E.J. (2007) Chapter 2: Traditional In-Situ Approaches to the Monitoring of Cryosphere Change. In: Slaymaker, O. and Kelly, R.E.J., Eds., The Cryosphere, Environmental Systems and Global Change Series, Blackwell Publishing, Malden, 49.

[34] National Research Council USA (2014) Opportunities to Use Remote Sensing in Understanding Permafrost and Related Ecological Characteristics: Report of a Workshop. The National Academies Press, Washington DC.

[35] Liljedahl, A.K., Boike, J., Daanen, R.P., Fedorov, A.N., Frost, G.V., Grosse, G., Hinzman, L.D., Iijma, Y., Jorgenson, J.C., Matveyeva, N., Necsoiu, M., Raynolds, M.K., Romanovsky, V.E., Schulla, J., Tape, K.D., Walker, D.A., Wilson, C.J., Yabuki, H. and Zona, D. (2016) Pan-Arctic Ice-Wedge Degradation in Warming Permafrost and Its Influence on Tundra Hydrology. Nature Geoscience, 9, 312-318. https://doi.org/10.1038/ngeo2674

[36] Shuur, E.A.G., Bockheim, J., Canadell, J.G., Euskirchen, E., Field, C.B., Goryachkin, S.V., Hagemann, S., Kuhry, P., Lafleur, P.M., Lee, H., Mazhitova, G., Nelson, F.E., Rinke, A., Romanovsky, V.E., Shiklomanov, N., Tarnocai, C., Venevsky, S., Vogel, J.G. and Zimov, S.A. (2008) Vulnerability of Permafrost Carbon to Climate Change: Implications for the Global Carbon Cycle. BioScience, 58, 701-714. https://doi.org/10.1641/B580807

[37] Zhu, Z., Piao, S., Myneni, R.B., Huang, M., Zeng, Z., Canadell, J.G., Ciais, P., Sitch, S., Friedlingstein, P., Arneth, A., Cao, C., Cheng, L., Kato, E., Koven, C., Li, Y., Lian, X., Liu, Y., Liu, R., Mao, J., Pan, Y., Peng, S., Penuelas, J., Poulter, B., Pugh, T.A.M., 
Stocker, B.D., Viovy, N., Wang, X., Wang, Y., Xiao, Z., Yang, H., Zaehle, S. and Zeng, N. (2016), Greening of the Earth and Its Drivers. Nature Climate Change, 6, 791-795. https://doi.org/10.1038/nclimate3004

[38] Biskaborn, B.K., Lanckman, J.-P., Lantuit, H., Elger, K., Streletskiy, D.A., Cable, W.L. and Romanovsky, V.E. (2015) The New Database of the Global Terrestrial Network for Permafrost (GTN-P). Earth System Science Data, 7, 245-259.

https://doi.org/10.5194/essd-7-245-2015

Submit or recommend next manuscript to SCIRP and we will provide best service for you:

Accepting pre-submission inquiries through Email, Facebook, LinkedIn, Twitter, etc. A wide selection of journals (inclusive of 9 subjects, more than 200 journals) Providing 24-hour high-quality service User-friendly online submission system Fair and swift peer-review system Efficient typesetting and proofreading procedure Display of the result of downloads and visits, as well as the number of cited articles Maximum dissemination of your research work

Submit your manuscript at: http://papersubmission.scirp.org/ Or contact gep@scirp.org 